DOI: $10.34185 / 1991-7848.2021 .01 .12$

UDC 669.162.22+267.4

Yu. Stupak, T. Khokhlova ${ }^{12}$

\title{
ON SOME ASPECTS OF THE STUDY OF PULVERIZED COAL AND FUEL MIXTURES COMBUSTION IN A DROP TUBE FURNACE
}

The article considers some aspects of the pulverized fuel combustion modelling in the laboratory on installations called vertical tube furnaces (referred to as drop tube furnaces in scientific periodicals). We have considered the scheme of the installation to study the process of pulverized coal (PC) combustion in conditions similar to the conditions of heating and ignition of coal particles in the blast flow of the blast furnace and their subsequent gasification in the raceway. We have formulated the basic requirements for ensuring the reliability of modelling results. We have examined the methods of combustion completeness (burnout) estimation used in similar studies. We have proposed a convenient method for the estimation of the burnout of two-component fuel mixtures. According to this method, the estimation can be performed for any ratio of components in a two-component fuel mixture with the use of data on the initial ash content in each of them and the relevant burnout. We have obtained the estimated data on the dependence of the burnout of PC (anthracite, lean coal) with fuel additives. It has been shown that the proposed approach can be used to evaluate experimental data regarding the study of the combustion completeness of fuel mixtures. It has been established that for the initial stages of PC combustion (heating, emission and ignition of volatile matters), which occur before the fuel particles enter the blast furnace raceway, the fuel mixtures burnout values recorded in the experiments do not differ significantly from the estimated ones. For the final stages of PC combustion (heating and burnout of char), which occur mainly in the raceway and outside, the combustion completeness determined in laboratory studies was significantly higher than the estimated one. The obtained results confirmed the efficiency in the use of drop tube furnace to model the PC combustion process during the fuel injection with the heated blast flow in the blast furnace raceways and study of the influence of various factors on the combustion process. The results of such studies can be used to improve the design of PC injection units in the blast furnace and to study the possibilities for improving the coal particles combustion completeness and the specific consumption of PC.

Keywords: blast furnace, tuyere, raceway, pulverized coal (PC), drop tube furnace, fuel mixtures, additives, volatile matter, combustion completeness, burnout.

(C) Stupak Yu., Khokhlova T., 2021 


\section{Problem statement}

In the technology of pig iron smelting with the use of pulverized coal (PC), which is widely used in modern metallurgy, the use of fuel mixtures is promising, which is confirmed in practice, due to the growing shortage of quality coal. But the effective use of mixtures containing low-quality fuel or its substitutes such as waste from agricultural and other industries requires further research. One of the ways of such research consists in modelling of the PC combustion using the drop tube furnaces. This method is widely used by researchers and allows us to obtain results of practical value for the development of the processes of pyrolysis and gasification of various fuels, including those in power plants. But the methodology of laboratory studies with the simulation of combustion conditions which are similar to the conditions of PC combustion when injected into a blast furnace requires further development and refinement based on the gathered experience. The methodology for determining combustion completeness of mixtures in such studies also needs to be clarified.

\section{Analysis of recent studies and publications}

Coal usually has been and remains a raw material used for the production of PC for injection into blast furnaces. As a rule, it is unsuitable for coking, but it has high carbon content (anthracite, lean, etc.) and the lowest possible amount of ash and harmful impurities. At the end of the last century, the European plants of Tissen AG (now called ThyssenKrupp AG) and some others successfully tested and implemented the coal mixtures injection, with adding to the PC's main component a certain amount of coal with a high yield of volatile matters [1].

The A. Carpenter's monograph gives examples of injection of mixtures of PC with coal with a high yield of volatile matters, as well as with plastic waste, into a blast furnace. Concerning plastic waste, it is suggested that the interaction between coal and plastic waste can be used to increase PC combustion efficiency. Also, it can help to maximize furnace productivity while reducing costs and minimizing environmental impact. Among the problems with plastics, the author indicates the difficulty of their preparation to ensure a stable fractional and chemical 
composition. Regarding coal mixtures, there are examples in which the flammability of PC from low-reaction coal is enhanced by mixing with coal with a high yield of volatile matters. However, the author raises the question of the need to further refine the relevant laboratory techniques and to verify the conformity of experimental data on the combustion of the mixtures with the conditions in the blast furnace. It is also emphasized the need to develop standard tests for evaluation of coal and plastic waste, standard tests for determining the reactivity of coal or plastic waste, and so forth. The main requirement is the compatibility of the test conditions with the conditions of the blast furnace [2].

Since the early 2000s, there have been more and more publications of studies on the combustion of new fuels, such as biomass of various origins and their derivatives, household waste such as rubber or plastics. For example, promising innovations in Japan involve combined injection scenarios in which crushed ore or renewable materials, such as biomass or plastic waste, are injected into blast furnaces through blow tuyeres. It is expected that such technologies can help to solve today's problems related to carbon emissions, energy production and resource availability [3]. However, the use of biomass in the metallurgical industry is still limited, and it is in strong competition with fossil fuels. As noted in publications [4, 5], the problems of biomass use in the metallurgical industry include technical and economic aspects that require synergies between the steel and bioenergy sectors.

Based on the above, it was advisable to compare the method developed and improved with the involvement of the author $[6,7]$, with those used in similar studies. The results of the analysis are shown in Table 1.

These examples became the motive for the refinement of the laboratory experiments method for modelling the combustion of PC and fuel mixtures using a drop tube furnace, as well as the methods for the evaluation of combustion process completeness and the influence of various factors on it. 
Table 1

Comparison of methods for calculating pulverized fuel combustion completeness used in some laboratory studies

\begin{tabular}{|c|c|c|c|c|}
\hline Name* & Unit & Formula for calculation & Comments & Source \\
\hline $\begin{array}{l}\text { Combustion } \\
\text { completeness }\end{array}$ & $\%$ & {$\left[1-\frac{A_{\mathrm{PCl}}\left(100-A_{\mathrm{res}}\right)}{A_{\mathrm{res}}\left(100-A_{\mathrm{PC}}\right)}\right] \times 100$} & $\begin{array}{l}A_{\mathrm{PC}}-\text { ash } \\
\text { content in } \\
\text { the original } \\
\mathrm{PC} ; \\
A_{\text {res }}-\text { ash } \\
\text { content in } \\
\text { the residue } \\
\text { after } \\
\text { combustion }\end{array}$ & [7] \\
\hline Burnout & $\%$ & {$\left[1-\left(\frac{A s h_{\text {coal }}}{100-A s h_{\text {coal }}}\right)\left(\frac{100-A s h_{\text {char }}}{A s h_{\text {char }}}\right)\right] \times 100$} & $\begin{array}{l}\text { Ash coal - ash } \\
\text { content in } \\
\text { the original } \\
\text { coal; } \\
\text { Ash } h_{\mathrm{rc}}-\text { ash } \\
\text { content in } \\
\text { the residue } \\
\text { after } \\
\text { combustion }\end{array}$ & [8] \\
\hline Burnout & $\%$ & $\frac{A s h_{\mathrm{uc}}-A s h_{\mathrm{rc}}}{A s h_{\mathrm{uc}}\left(1-\frac{A s h_{\mathrm{rc}}}{100}\right)} \times 100$ & $\begin{array}{l}\text { Ash } h_{\mathrm{uc}}-\text { ash } \\
\text { content in } \\
\text { the residue } \\
\text { after } \\
\text { combustion; } \\
\text { Ash } h_{\mathrm{rc}}-\text { ash } \\
\text { content in } \\
\text { the original } \\
\text { coal }\end{array}$ & [9] \\
\hline $\begin{array}{l}\text { Fixed carbon } \\
\text { burnout }\end{array}$ & $\begin{array}{l}\text { Unit } \\
\text { fr. }\end{array}$ & $1-\left(\frac{\% C_{\text {final }} \times \% A s h_{\text {initial }}}{\% C_{\text {initial }} \times \% A s h_{\text {final }}}\right.$ & $\begin{array}{l}\% C_{\text {initial }} \text { and } \\
\% A s h_{\text {initial }}- \\
\text { content of } \\
\text { carbon and } \\
\text { ash in the } \\
\text { original fuel, } \\
\text { respectively; } \\
\% C_{\text {final and }} \\
\% A s h_{\text {final }}- \\
\text { the same in } \\
\text { the residue } \\
\text { after } \\
\text { combustion }\end{array}$ & [10] \\
\hline
\end{tabular}

* - reproduced according to the source materials 


\begin{tabular}{|c|c|c|c|c|}
\hline Name* & Unit & Formula for calculation & Comments & Source \\
\hline $\begin{array}{l}\text { Combustion } \\
\text { ratio }\end{array}$ & $\%$ & $100-\left(\frac{X_{a} \times A_{b}}{X_{b} \times A_{a}}\right) \times 100$ & $\begin{array}{l}X_{a} \text { and } X_{b}- \\
\text { carbon } \\
\text { content in } \\
\text { the semi- } \\
\text { coke particles } \\
\text { and the raw } \\
\text { coal, } \\
\text { respectively; } \\
A_{a} \text { and } A_{b}- \\
\text { ash content } \\
\text { in the semi- } \\
\text { coke particles } \\
\text { and the raw } \\
\text { coal, } \\
\text { respectively }\end{array}$ & {$[11]$} \\
\hline Burnout & $\%$ & $\frac{10^{4}\left(A_{1}-A_{0}\right)}{A_{1}\left(100-A_{0}\right)}$ & $\begin{array}{l}A_{0}-\text { ash } \\
\text { content in } \\
\text { the original } \\
\text { coal; } \\
A_{1}-\text { ash } \\
\text { content in } \\
\text { the residue } \\
\text { after } \\
\text { combustion }\end{array}$ & {$[12]$} \\
\hline Char burnout & $\begin{array}{l}\text { Mass } \\
\text { fr. }\end{array}$ & $\frac{f_{a}-f_{a, 0}}{f_{a}\left(1-f_{a, 0}\right)}$ & $\begin{array}{l}f_{a} \text { and } f_{a, 0}- \\
\text { mass } \\
\text { fractions of } \\
\text { ash in the } \\
\text { residue after } \\
\text { combustion } \\
\text { and the } \\
\text { original fuel, } \\
\text { respectively }\end{array}$ & [13] \\
\hline
\end{tabular}

* - reproduced according to the source materials

\section{The purpose of the study}

The purpose of the study is to clarify the method of studying the combustion of PC, which is a mixture of coal with different degrees of metamorphism or contains several other types of pulverized flammable fuels. More accurate information on the processes that occur during the combustion and gasification of fuel particles in the hot blast and the blast furnace raceway is extremely important for the improvement of the PC injection technology, which is widely used in many enterprises. 


\section{The substantive material of the study}

\subsection{Method}

The study of the pulverized fuel flow combustion was carried out in the drop tube furnace, the concept of which was developed under the guidance of P. Bondarenko and V. Kotov [6]. Later, this installation was improved in order to eliminate some shortcomings and expand the possibilities for modelling the final stages of PC combustion [7]. You can see a simplified principle diagram in Figure 1.

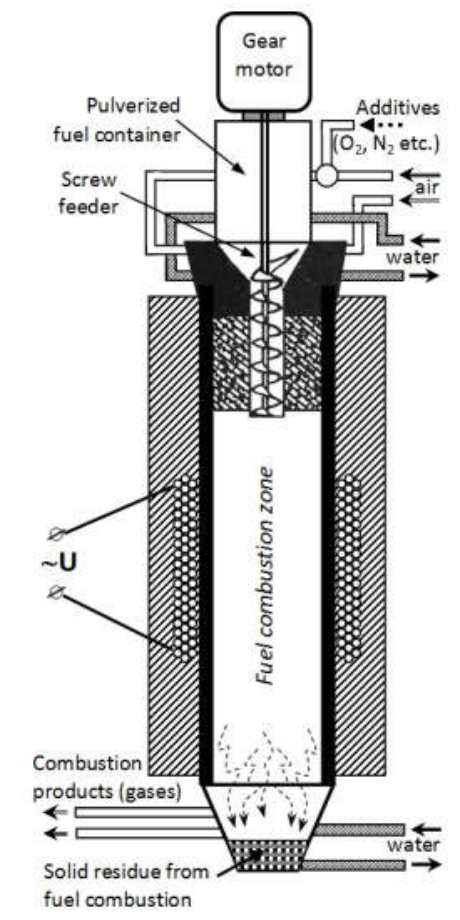

Figure 1 - Drop tube furnace scheme

In the upper part of the furnace the most critical unit of the installation is set: it is a screw feeder which provides the pulverized fuel to the combustion zone. In addition to the injection of fuel, this unit must provide oxidant delivery and uniform distribution of the oxidant, as well as cooling of the feeder structure elements to prevent premature heating of the fuel and other negative consequences. The combustion products and accumulation of the fuel residues after combustion are removed in the lower part.

Taking into account our own experience, as well as the results of experiments with the use of similar equipment of other researchers [8-13, etc.], the following basic requirements were met in the manufacture of the installation (Figure 1):

- the combustion zone of the furnace, where combustion takes place, had a clearly defined and unchanged over time isothermal zone of the required (under the conditions of modelling the combustion process) length;

- the design (technical characteristics) of the feeder provided acceptable dosing accuracy, stability and consistency of fuel consumption and its ratio to the oxidant (air, oxygen, etc.) throughout the experiment (series of experiments);

- the design of the cooler, mounted in the lower part of the furnace, provided a rapid stop of the combustion process (without smouldering) of fuel residues that have reached the lower part of the furnace; 
- technical analysis of the raw fuel, as well as the residue after its combustion, was performed according to the requirements of the relevant standards $[14,15]$.

To evaluate the results of the fuel combustion process modelling, we used an advanced method [7], which was used to calculate the so-called combustion completeness (burnout) for a particular fuel. The main advantage of the method is the relative simplicity: only the data on the ash content in the raw fuel and in the residue after its combustion are used in the calculations. Comparison of this method with others (Table 1), which was given at the beginning, showed its acceptability in relation to the purposes of the study and the absence of fundamental differences with the approaches used in similar studies.

Several types of coal with different degrees of metamorphism, as well as peat and lignin were used in pulverized fuel fabrication. The raw coal and other fuels after drying were ground to a powdery state in a ball drum mill. The particles were ground to the size that meets the requirements for the PC fractional composition for injection into the blast furnace. The control of the fractional composition of pulverized fuel after grinding was carried out on vibromechanical sieves Fritsh Analysette. Technical analysis and fractional composition of fuels used in the studies are shown in Table 2.

Table 2

Proximate analysis and fractional composition of coal, peat and lignin

\begin{tabular}{|c|c|c|c|c|c|c|c|}
\hline \multirow{2}{*}{ Type of fuel } & \multicolumn{4}{|c|}{ Proximate analysis, $\%$} & \multicolumn{3}{|c|}{ Distribution by size, \% (by weight) } \\
\hline & $W_{t}^{r}$ & $A^{d}$ & $S_{t}^{d}$ & $V^{\text {daf }}$ & $250-100 \mu \mathrm{m}$ & $100-71 \mu \mathrm{m}$ & $<70 \mu \mathrm{m}$ \\
\hline $\begin{array}{l}\text { COAL: } \\
\text { Anthracite }\end{array}$ & 6.7 & 17.2 & 1.26 & 4.8 & 39.9 & 31.6 & 28.5 \\
\hline Lean coal & 10.0 & 9.5 & 1.82 & 10.6 & 29.8 & 40.8 & 29.4 \\
\hline Coal G & 11.6 & 11.4 & 1.66 & 35.6 & 13.7 & 45.7 & 40.6 \\
\hline Coal D & 12.6 & 26.3 & 1.38 & 40.0 & 17.8 & 33.0 & 49.2 \\
\hline Coal B & 58.0 & 17.9 & 3.22 & 68.7 & 42.2 & 26.3 & 31.5 \\
\hline Peat & 55.0 & 30.6 & 0.28 & 62.8 & 10.2 & 22.6 & 67.2 \\
\hline Lignin* & 60.0 & 15.9 & 0.69 & 63.8 & 27.6 & 24.9 & 47.5 \\
\hline
\end{tabular}

* - product of processing (acid process) of agricultural waste and wood chips

The isothermal zone of the furnace combustion zone (Figure 1) was constructed in such a way as to equal the residence time of the fuel to the residence time of PC particles entering the hot blast flow of the blast furnace at a point away from the tuyere cut by $0.3 \ldots 0.6 \mathrm{~m}$. This time was $0.01 \ldots 0.02 \mathrm{~s}$, which corresponds to the estimates given in $[16,17]$, as well as to more recent ones, according to which the 
residence time of coal particles in the PC plume before reaching the end of the raceway is about $0.01 \ldots 0.05 \mathrm{~s}$ [18]. Ensuring a stable and time-constant ratio between $C_{f}$ and $\mathrm{O}_{b}\left(C_{f}-\right.$ carbon content in the fuel, $\mathrm{O}_{b}$ - oxygen content in the atmosphere into which the fuel is released) was an important condition for modelling. Based on this ratio, the feeder productivity was calculated and the air flow was controlled (with or without oxygen).

\subsection{Results and their discussion}

Studies of previous years, the results of which were highlighted at the beginning of the article, showed the possibility to significantly intensify the PC combustion by adding coal with a high yield of volatile matters, as well as other fuel additives with low ignition temperature. But the next question remained unresolved, namely whether the higher completeness of fuel mixtures combustion is a consequence of mechanical mixing of individual results of combustion of two types of fuel, one of which has significantly higher flammability (combustion completeness in identical conditions).

To find the answer to this question, we composed and solved a system of six equations at the first stage:

$$
\begin{gathered}
\phi_{1}=\left[1-\frac{A_{1}^{d}\left(100-A_{\text {res } 1}^{d}\right)}{A_{\text {res } 1}^{d}\left(100-A_{1}^{d}\right)}\right] \times 100 ; A_{\text {mix }}^{d}=A_{1}^{d} d_{1}+A_{2}^{d} d_{2} ; \\
\phi_{2}=\left[1-\frac{A_{2}^{d}\left(100-A_{\text {res } 2)}^{d}\right)}{A_{\text {res } 2}^{d}\left(100-A_{2}^{d}\right)}\right] \times 100 ; A_{\text {res }}^{d}=A_{\text {res }}^{d} d_{1}+A_{\text {res } 2}^{d} d_{2} ; \\
\left.\phi_{\text {mix }}=\left[1-\frac{A_{\text {mix }}^{d}\left(100-A_{\text {res }}^{d}\right)}{A_{\text {res }}^{d}\left(100-A_{\text {mix }}^{d}\right)}\right)\right] \times 100 ; d_{1}+d_{2}=1,
\end{gathered}
$$

where $\varphi_{1}, \varphi_{2}$ and $\varphi_{\text {mix }}$ are the combustion completeness (burnout) of the first and the second fuel of the mixture, as well as the mixture itself, calculated according to the method [6]; $A_{1}^{d}, A_{2}^{d}, A_{\text {mix }}^{d}$ and $A_{\text {res }}^{d}$ are the ash content in the first and the second fuel, in the initial mixture and in the residue from its combustion (\% by dry mass) respectively; $d_{1}$ and $d_{2}$ respectively are the share of basic fuel and fuel additive in the mixture.

As a result, we obtained an equation describing the dependence of the combustion completeness (burnout) of any two-component fuel mixture $\left(\varphi_{\text {mix }}\right)$ on the amount of fuel additive $(d)$ contained in it: 


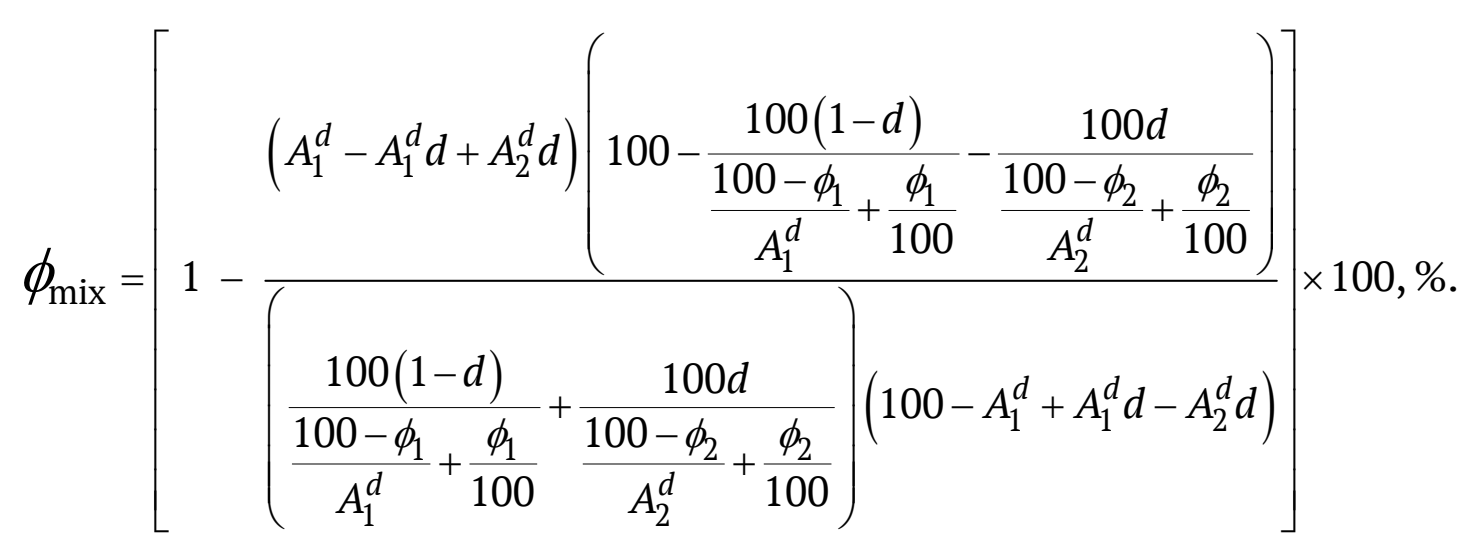

As can be seen from equation (1), the calculation of the fuel mixtures combustion completeness (burnout) requires data on the burnout of each fuel $(\varphi)$ under conditions identical to the conditions of mixture combustion. For the fuels shown in Table 2, such data were obtained experimentally (Table 3). Experiments on the modelling of combustion in the initial stages (before the PC enters the raceway) were performed in the furnace shown in Figure 1. Modelling of the final stages was performed on the same equipment, but with some design differences which are considered in [6]. All studies of the PC and fuel mixtures combustion were carried out in normal ambient air without oxygen enrichment.

Table 3

Data on the combustion completeness of pure fuels $(\varphi, \%)$

obtained experimentally in the furnace during PC combustion modelling (Figure 1)

\begin{tabular}{|c|c|c|c|c|c|c|c|}
\hline \multirow{2}{*}{$\begin{array}{l}\text { Stages of PC } \\
\text { combustion }\end{array}$} & \multicolumn{5}{|l|}{ Coal } & \multirow{2}{*}{ Peat } & \multirow{2}{*}{ Lignin } \\
\hline & Anthracite & Lean & Coal G & Coal D & Coal B & & \\
\hline Initial & 12.2 & 17.4 & 41.4 & 44.1 & 51.4 & 59.6 & 56.5 \\
\hline Final & 43.1 & 45.8 & 65.4 & 67.2 & 69.8 & 76.9 & 73.9 \\
\hline
\end{tabular}

Using the obtained data (Table 3) with the equation (1) in the Excel spreadsheet environment, we obtained the dependences $\varphi_{\text {mix }}=f(d)$ for two-component mixtures of anthracite and lean coal with fuel additives. The proportion of additives $(d)$ was varied from 0 to $50 \%$. The results of the calculations are shown in Figure 2 and Figure 3. 

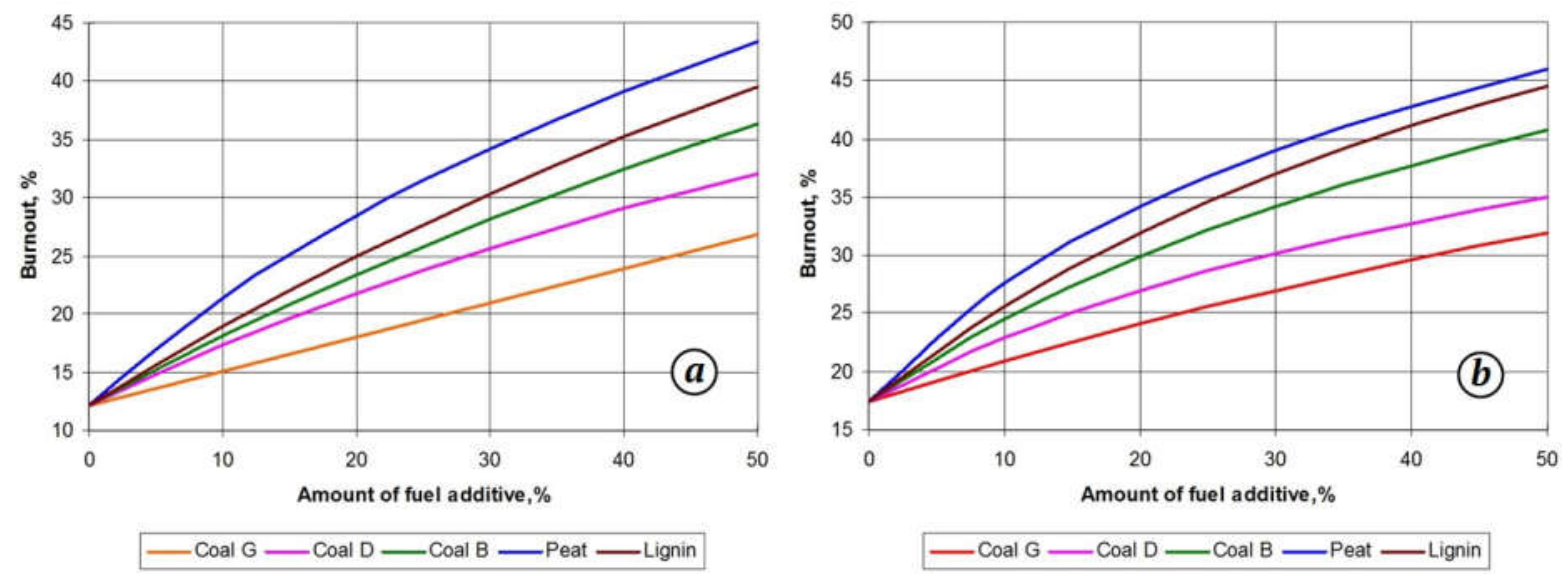

Figure 2 - Fuel mixture burnout (initial stages of combustion) depending on fuel additive amount: $a$ - mixtures with anthracite; $b$ - mixtures with lean coal
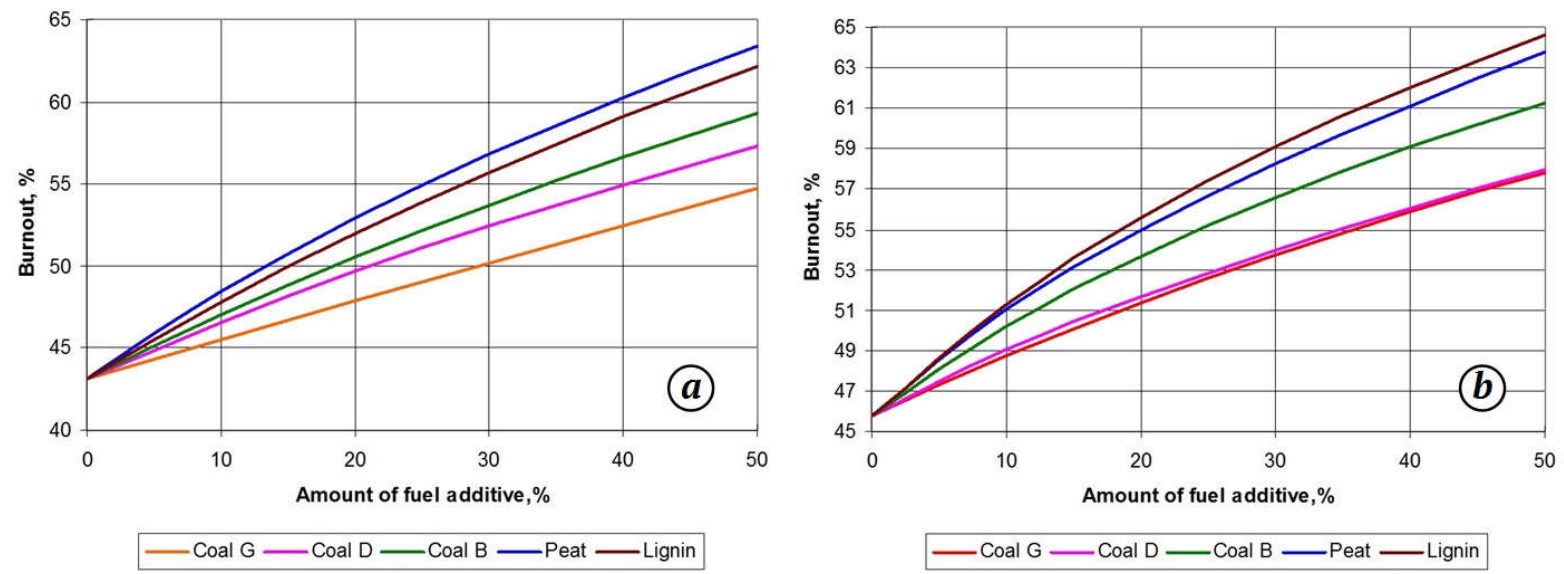

Figure 3 - Fuel mixture burnout (final stages of combustion) depending on fuel additive amount: $a$ - mixtures with anthracite; $b$ - mixtures with lean coal

The results of the calculations shown in Figure 2 and Figure 3 were compared with experimental data regarding the fuel mixtures combustion completeness (burnout) in the initial and final stages of the combustion process. This comparison revealed that in the initial stages of the PC combustion process the experimentally determined combustion completeness of mixtures with the addition of fuels with a high yield of volatile matters does not exceed the calculated one. This is due to the short residence time of the fuel particles in the furnace's isothermal zone (in practice, in the hot blast flow in the area from the point of entry to the tuyere cut) and the rapid release of volatile matters from the relevant fuel additive. The latter is a significant barrier to the contact of oxygen molecules with the carbon skeleton of fuel particles. In the final stages, in contrast to the initial stages, the completeness of fuel mixtures combustion in the experiments was higher than the calculated one. With an increase in the share of additives in the fuel mixture over 15-20\% (depending on the type of additive), the difference between the theoretical and the experimental combustion completeness increased markedly. It should be noted that 
due to the small amount of experimental data, the obtained results need further clarification and are the subject of further research.

\section{Conclusions and prospects for further studies}

The analysis of recent publications has shown that the use of coal mixtures in energy and metallurgy, as well as fuel additives to PC such as biomass, wastes such as rubber or plastics, is very promising. We have considered the structure of experimental installation and the method for modelling the process of combustion of fuel mixtures during their injection into the blast furnace. We have offered the formula for the calculation of combustion completeness of PC mixtures with fuel additives. The obtained results allow us to summarize the following:

- in the initial stages of the PC combustion process, occurring in the inner space of the tuyere and partially in the raceway, the experimentally determined combustion completeness of mixtures with the addition of fuels with a high yield of volatile matters does not exceed the calculated one;

- in the final stages, the fuel mixtures combustion completeness in the experiments was higher. With an increase in the share of additives in the fuel mixture over 15-20\% (depending on the type of additive), the difference between the theoretical and the experimental combustion completeness increased markedly;

- the proposed formula can be used to estimate the combustion completeness of coal mixtures of different quality, as well as PC with the addition of peat and other fuels containing carbon. The possibility to use the proposed formula in studies of PC combustion with the addition of wastes such as rubber or plastics needs to be clarified.

\section{REFERENCES}

1. Gudenau H. Kohlenstaubeinblasen in den Hochofen - Steirung der Einblasrate durch den Einsatz von Kohlemischungen / H.W. Gudenau, B. Korthas, R. Kiesler, L. Birkhauser // Stahl und Eisen. 1990. - №11. -P. 35-40.

2. Carpenter A. Injection of coal and waste plastics in BFs. IEA Clean Coal Centre, March 2010. https://www.iea-coal.org/report/injection-of-coal-and-waste-plastics-in-blast-furnaces-ccc-166/

3. Clean Coal Technologies in Japan. Technological Innovation in the Coal Industry. 2nd Edition. NEDO. Kawasaki City, 2015. 148 p. https://www.nedo.go.jp/content/100861237.pdf

4. Mousa E. Biomass applications in iron and steel industry: An overview of challenges and opportunities / Elsayed Mousa, Chuan Wang, Johan Riesbeck, Mikael Larsson // Renewable and Sustainable Energy Reviews. -2016. -Vol. 65. -P. 1247-1266.

5. Mousa E. Modern blast furnace ironmaking technology: potentials to meet the demand of high hot metal production and lower energy consumption / Elsayed Mousa // Metall. Mater. Eng. -2019. Vol. 25 (2). -P. 69-104. https://doi.org/10.30544/414

6. Bondarenko P. Pulverized coal combustion process modelling in the blast furnace tuyere / P.K. Bondarenko, V.I. Kotov, Yu.A. Stupak // Izvestiya. Ferrous Metallurgy ("Izvestiya vuzov. Chernaya metallurgiya"). -1990. - №7. -P. 103.

7. Stupak Yu. Study of the pulverized coal combustion process in laboratory conditions / Yu.A. Stupak // Izvestiya. Ferrous Metallurgy ("Izvestiya vuzov. Chernaya metallurgiya"). -1993. -№8. P. 35-36. 
8. Carpenter A. Coal combustion: Analysis and testing / Anne M. Carpenter, Nina M. Skorupska // IEA Coal Research/64. London: IEA. - 1993. - 97 p. https://lib.ugent.be/catalog/rug01:000303332

9. Du Sh. Pulverized coal burnout in blast furnace simulated by a drop tube furnace / Shan-Wen Du, Wei-Hsin Chen, John A. Lucas // Energy. -2010. -Vol. 35. -P. 576-581. DOI: 10.1016/j.energy.2009.10.028.

10. Halder S. An Experimental Perspective on Praxair's Hot Oxygen Technology to Enhance Pulverized Solid Fuel Combustion for Ironmaking Blast Furnaces / Sabuj Halder // Praxair Inc. -2011. http://www.praxair.com/praxair.nsf/AllContent/31B770CF22B3FBBF8525799F0075226F

11.Ueki Ya. Combustion Behavior of Pulverized Coal and Ash Particle Properties during Combustion / Yasuaki Ueki, Ryo Yoshiie, Ichiro Naruse // ISIJ International. -2015. -Vol. 55. -№ 6. -P. 13051312.

12. Steer Ju. The effects of particle grinding on the burnout and surface chemistry of coals in a drop tube furnace / Julian M. Steer, Richard Marsh, David Morgan, Mark Greenslade // Fuel. -2015. Vol. 160. -P. 413-423.

13.Lewtak R. Coal char kinetics of oxidation and gasification reactions / Robert Lewtak, Jarosław Hercog // Chemical and Process Engineering. -2017. -Vol. 38(1). -P. 135-145. DOI: 10.1515/cpe2017-0011.

14.Coal. Technical analysis: DSTU ISO 17246: 2010. [Valid from 2012-01-07]. -Kyiv: Derzhspozhyvstandart Ukrainy, 2014. $-4 \mathrm{p}$.

15. Solid mineral fuel. Methods for determining ash content. GOST 11022-95 (ISO 1171-97). [Valid from 1997-07-01]. -Minsk: IPK "Publishing house of standards", 1996. -8 p.

16. Dunaev N. Injection of pulverized materials into blast furnaces / N.E. Dunaev, Z.M. Kudryavtseva, Yu.M. Kuznetsov. -M .: Metallurgy, 1977. -208 p.

17. Guo Yu. Injection de poudre de charbon dans le haut fourneau / Yun-zhi Guo, Yun-cai Liu // Rev. $\begin{array}{lllllll}\text { Met. Paris. } & -1980 . & - \text { Vol. } & 77 . & -\mathrm{N} N 10 . & \text {-P. } & \text { 841-851. DOI: }\end{array}$ https://doi.org/10.1051/metal/198077100841.

18. Shen Y. Three-dimensional modelling of in-furnace coal/coke combustion in a blast furnace / Y.S. Shen, B.Y. Guo, A.B. Yu, P.R. Austin, P. Zulli // Fuel. -2011. -Vol. 90. Issue 2. -P. 728-738.

Received 22.01.2021. Accepted 03.02.2021.

УДК 669.162.22+267.4

Ю.О. Ступак, Т.С. Хохлова

\section{ПРО ДЕЯКІ АСПЕКТИ ДОСЛІДЖЕННЯ ГОРІННЯ ПИЛОВУГІЛЬНОГО ПАЛИВА ТА ПАЛИВНИХ СУМІШЕЙ У ВЕРТИКАЛЬНІЙ ТРУБЧАСТІЙ ПЕЧІ}

У статті розглянуті окремі аспекти моделювання горіння пилоподібного палива в лабораторних умовах на установках типу «вертикальна трубчаста піч» (в науковій періодиці - drop tube furnace). Розглянуто схему установки для дослідження процесу горіння пиловугільного палива (ПВП) в умовах, що подібні до умов нагріву та займання часток вугілля в потоці дуття доменної печі та їх подальшої газифікації у фурменому осередку. Сформульовані основні вимоги щодо забезпечення надійності результатів моделювання. Досліджені способи оцінки повноти згорання, що застосовуються в подібних дослідженнях. Запропонований зручний спосіб розрахункової оцінки повноти згорання двокомпонентних паливних сумішей. За цим способом розрахунок може здійснюватися для будь-яких співвідношень компонентів у двокомпонентній суміші палив з використанням даних щодо вихідного вмісту золи в кожному та відповідної повноти згорання. Отримані розрахункові дані щодо залежності повноти згорання ПВП 3 антрациту та пісного вугілля 3 паливними добавками. Показано, що запропонований підхід може застосовуватися для оцінки 
експериментальних даних 3 вивчення повноти згорання паливних сумішей. Встановлено, що для початкових стадій горіння ПВП (нагрів, виділення та займання летких речовин), які відбуваються ще до потрапляння часток палива до фурменого осередку доменної печі, значення повноти згорання паливних сумішей, що фіксувалися в експериментах, суттєво не відрізняються від розрахункових. Для заключних стадій горіння ПВП (нагрів та вигорання вуглецевого залишку), що відбуваються переважно у фурменому осередку та за його межами, повнота згорання, визначена в лабораторних дослідженнях, виявилася помітно вищою за розрахункову. Отримані результати підтвердили ефективність використання установки типу «вертикальна трубчаста піч» для моделювання процесу горіння ПВП при введенні палива з потоком нагрітого дуття у фурмені осередки доменної печі та дослідження впливу на процес горіння різних факторів. Результати подібних досліджень можуть використовуватися для вдосконалення конструкцій вузлів введення ПВП в доменну піч і вивчення можливостей щодо підвищення повноти згорання часток вугілля та питомої витрати ПВП.

Ключові слова: доменна піч, фурма, фурмене вогнище, пиловугільне паливо (ПВП), вертикальна трубчаста піч, суміші палива, добавки, летючі речовини,повнота згорання, вигорання.

Ступак Юрій Олександрович - кандидат технічних наук, доцент, завідувач кафедри теорії, технології та автоматизації металургійних процесів, секретар Вченої ради навчально-наукового інституту інтегрованих форм навчання, Національна металургійна академія України, м Дніпро.

Хохлова Тетяна Станіславівна - кандидат технічних наук, професор, професор кафедри термічної обробки металів ім. К.Ф.Стародубова, директор навчальнонаукового інституту інтегрованих форм навчання, Національна металургійна академія України, м Дніпро.

Ступак Юрий Александрович - кандидат технических наук, доцент, заведующий кафедрой теории, технологии и автоматизации металлургических процессов, секретарь Ученого совета учебно-научного института интегрированных форм обучения, Национальная металлургическая академия Украины, г. Днепр.

Хохлова Татьяна Станиславовна - кандидат технических наук, профессор, профессор кафедры термической обработки металлов им. К.Ф.Стародубова, директор учебно-научного института интегрированных форм обучения, Национальная металлургическая академия Украины, г. Днепр.

Stupak Yurii - Candidate of Technical Sciences, Associate Professor, Head of the Department of Theory, Technology and Automation of Metallurgical Processes, Secretary of the Academic Council of the Educational-Scientific Institute of Integrated Education, The National Metallurgical Academy of Ukraine, Dnipro.

Khokhlova Tatyana - Candidate of Technical Sciences, Professor, Professor of the Department of Heat Treatment of Metals named after K.F. Starodubov, Director of the Educational-Scientific Institute of Integrated Education, The National Metallurgical Academy of Ukraine, Dnipro. 